\title{
The Supply of Quality Workers and the Demand for Quality in Jobs in Japan's Early Industrialization*
}

\author{
Gary R. Saxonhouse \\ The University of Michigan
}

\section{INTRODUCTION}

In the West, historical treatments of the rise of the factory system have always stressed the attitudes, pressures, and discontents of the workers. Despite this historical interest most economic analysis of early European and American industrialization has stressed changes not in the supply but in the demand for labor, particularly technological developments, capital accumulation, and the opening of markets. Not surprisingly, the few systematic international historical comparisons of labor supply which have been made have come up with widely diverse conclusions. Morris (1960) concludes explicitly that labor supply was a "slack variable" and extends this assertion not only to India (1855-1914) but to Great Britain (1770-1830) and remarkably to New England (1792-1840): "In no case did the shortage of skilled labor . . . inhibit the pace at which the industry would otherwise have expanded . . . I think it is safe to say that the supply of raw unskilled labor was never an inhibiting factor in economic growth." In contrast Gerschenkron (1962) has made the inelasticity of the supply of such labor in the early stages of development, regardless of national demographics, a foundation block in his understanding of the industrial development of the various continental European countries. Lacking the traits of stability, reliability, and discipline, it is argued the underemployed peasants and urban poor of nineteenth-century Central and Eastern Europe did not necessarily translate into a ready supply of labor for the newly borrowed Western European factory system.

For Japan, quite unlike the experience of Europe and the United States, historical economists and economic historians have not neglected the description and economic analysis of the supply of labor in early industrialization. Drawing on an already venerable Marxist tradition in the 1920s and 1930s, academic members of the two Marxist factions, the

\footnotetext{
* This paper is part of a joint project of Comparative Studies of Labor Markets in Early Industrialization undertaken with Gavin Wright and sponsored by the National Science Foundation.
} 
Koza-ha and the Rōnō-ha, developed proto-two-sector models of Japanese economic development which among other contributions analyzed how changes in agricultural conditions might affect the terms of labor supply to the industrial sector. ${ }^{1}$ In the postwar period, Ohkawa (1955), seemingly building on some insights by Koza-ha writers, developed a highly influential model which rationalized the coexistence of Japanese unemployment with equilibrium conditions by assuming average productivity pricing of labor in agriculture and marginal productivity pricing in industrial employment. Supply of labor to industry was governed by the average productivity of labor in agriculture while demand was governed by industry's marginal productivity of labor curve. ${ }^{2}$

Ohkawa's theoretical apparatus has shaped the writing of modern Japanese economic history. In both Ohkawa's Japanese language writing on Japan's economic evolution and his English language collaboration with Rosovsky (1973) its influence is almost transparent. The creation and growth of a modern industrial sector in the midst of a traditional agricultural economy fed by elastic supplies of labor and the final destruction of the traditional sector are themes which dominate Ohkawa's empirical work.

Ohkawa's view that Japan's industrial sector fed on elastic supplies of labor from the traditional sector [a view compatible with Morris (1960)] is explicitly contrasted with Gershenkron's historical finding that for continental Europe underemployment of labor is not synonymous with elastic supplies of labor to a nascent industrial sector in Rosovsky's Capital Formation in Japan. Rosovsky finds that Japan, unlike Germany and Russia, could quickly make a disciplined and reliable labor force out of its underemployed population.

There is both direct and indirect evidence that Japan was capable of forming a disciplined and reliable labor force, suitable for factory work, more easily than many backward countries of continental Europe. The historical record such as it is, contains few complaints on this score. Population growth spewed forth labor

${ }^{1}$ Among other considerations these Marxist schools differed as to the mode of factor pricing in Japan's agricultural sector. The Koza-ha stressed the continuing importance of feudal institutions in Japanese economic life and argued for nonmarket forces determining rents and wages in the agricultural sector. On the other side, the Rōnō-ha saw Japan as a through-going bourgeois society since at least the late Tokugawa period. Wages and rents were seen as nonfeudal being determined by essentially neoclassical markets. A simplified exposition of some of this work is given in Yasuba (1968, 1972-1973) and Saxonhouse (1976a).

${ }^{2}$ Ohkawa's (1955) model has had wide influence in the West. With Lewis (1954), Ohkawa can claim to have had influence on the not fully neoclassical and very well-known development theories of Jorgenson (1961) and Fei and Ranis (1964). Jorgenson like Ohkawa assumes average producitivity pricing of labor in agriculture and marginal productivity pricing of labor in industry. Fei and Ranis follow Lewis and assume an exogenously determined subsistence wage rate in agriculture but otherwise, use a two-sector analytical framework which draws heavily on Ohkawa's thinking. 
from the countryside, creating competition for industrial jobs; and even though it took a long time to cut the cord reaching to the rural areas, after a while the cord became stretched beyond recognition.

Rosovsky $(1961$, p. 123) explains Japan's success in this area by noting the survival of traditional institutions into the early factory system.

Sociologists tell us that Japanese society is very "integrated" and therefore may present lesser disciplinary problems. Others have emphasized innovating enterprising leadership, combined with teamwork and solidarity in group organization, "sufficient" to give order and momentum to the process of change contemplating factory employment, or more specifically servicing a machine, probably filled the early Japanese worker with a certain amount of horror. But the transition was made softer and smoother by the concessions which the factory was willing to make to him: he was still treated as a typical Japanese. . . . Japanese economic development has taken place with much less change from the kinds of social organization and social relations of pre-industrial or nonindustrial Japan than would be expected from the Western model of the growth of industrial society.

Rosovsky's writing on Japan's labor force in early industrialization remains an extreme statement of the view that (i) Japan had relatively elastic supplies of labor suitable for factory work; and (ii) the ease with which early Japanese industry obtained such labor may be attributed to culturally distinctive circumstances. ${ }^{3}$ Subsequent Western writers have emphasized the important Japanese scholarship and primary evidence which Rosovsky overlooked in drawing his conclusions. ${ }^{4}$ Indeed the pendulum has swung far in the other direction with Saxonhouse (1976b) now finding that the early Japanese factory textile labor force was more unstable and undisciplined than their historical counterparts elsewhere in Asia, in the Northern and Southern United States, and in

${ }^{3}$ In making his assessment of early Japanese labor markets Rosovsky (1961) grafted the idealized picture of the postwar Japanese factory drawn by the sociologist turned management consultant Abegglen (1958) into a Meiji era setting.

${ }^{4}$ In the West, Taira (1970) was among the earliest to use both Japanese scholarship and primary evidence to criticize the observation that the Meiji Japanese economy had underemployment in its traditional sector and/or that the Meiji industrial worker was well disciplined by comparison with the experience of other nascent modern labor forces. Among the important Japanese scholarship on prewar labor supply the writings of Kazuo Okochi and his students, Keizo Fujibayashi, and the Rōno-ha leader Takao Tsuchiya should not be neglected. In Rōdo mondai and in many other writings, Okochi analyzes the role of the dekasegi-gata - the industrial worker who has not cut his ties to the traditional sector. Fujibayashi (1960) was perhaps the first Japanese postwar economic historian to call particular attention to the high turnover rates of the mid-Meiji era. Finally, Takeo Tsuchiya, an extremely prolific and distinguished Japanese economic historian who has written on many topics, is noteworthy in this context among other efforts in having the Meiji-era government report Shokkō jijö reissued in 1948. The Shokkō jijō contains an excellent quantitative description of working conditions in early Japanese factories. When its three volumes were originally published in 1903 it had an impact comparable to the famous Sadler's Committee Report (1831-1832). 
continental Europe. ${ }^{5}$ Moreover, this finding is not rooted in an analysis which emphasizes the culturally inherent difficulties of using Japanese men and women on a long-term basis for textile factory work. ${ }^{6}$ Rather, Japan's early industrialists found the kind of labor force they wanted. This is not a case of a series of unsuccessful attempts to do what could not be done. The industry's offerings and the labor force's preferences and alternative opportunities and needs were simply never reconciled to strike the bargain which would create a stable, permanent labor force. Gerschenkron (1962) argued that underemployed labor notwithstanding, the absence of the traits of reliability, stability, and discipline in workers recently emerged from peasant society would force newly developing economies to adopt large-scale, capital intensive modes of production. A view more in accord with the Japanese experience would find the quality of the early industrial labor force to be as much a decision variable and market outcome as scale and factor proportions.

\section{THE SUPPLY OF QUALITY WORKERS AND THE DEMAND FOR QUALITY IN JOBS}

How did the market process fix the quality of labor? Most Japanese workers chose not to remain in the cotton textile industry because with only a few exceptions long-term opportunities for higher than agricultural wages in this industry came only at a cost. Good opportunities required experience and without mill-owner subsidies more experience meant lengthier periods in the mill receiving less than agricultural wages. Mill owners were most reluctant to finance this implicit cost for the worker. The unusual degree of technological homogeneity among Japanese textile firms made interfirm mobility of experienced workers potentially very easy. Thus, investment in the work force by the mill owner could not be easily recouped. Textile workers for their part were typically in no position to make such an investment. With opportunities thus constricted low wages and high turnover persisted for decades as the industry norm. ${ }^{7}$

${ }^{5}$ In Saxonhouse (1976b) instability is indexed primarily by turnover experience. Similar conclusions, however, can be drawn from examination of the rate of absenteeism. In 1913 (Uno, 1913) as in 1897 (Dai nihon bōseki rengōkai) the rate of absenteeism of workers living in company-owned dormitories was $8.5 \%$. While these rates may seem low by comparison with figures cited for other countries the contrary is true. Estimates collected for other textile industries (Morris, 1960) typically compare workers showing up against a hypothetical full staffing. When Japanese figures are put on the same basis the absentee rate jumps to at least $15 \%$.

- Before management discussion of modern Japanese labor relations became firmly rooted in Confucian rhetoric such analyses were not uncommon. Fukuhara (1903) suggests that Japanese textile workers, unlike Americans, are too rooted to their native places to ever become members of a permanent, stable industrial work force. Similarly, Kamisaka (1919) argues that Japanese textile workers are uniquely insensitive to pecuniary incentives.

${ }^{7}$ The analysis here is presented in full detail in Saxonhouse (1976b). 
This discussion of the transience and instability of the Japanese textile industry labor force ignores the paternalistic practices emphasized by Rosovsky in his account of the Meiji labor force. Over a long term, instability and indiscipline make strange bedfellows with paternalism. Yet this apparently was the case for at least 50 years in Japan. ${ }^{8}$ How do the paternalistic practices of the Japanese mill owners fit into the picture drawn here of a labor force whose indiscipline and instability was the accepted outcome of industry policies? It is easy to suggest that paternalism was a sham adopted from approved Confucian writing to mask the use of very young workers in what were by Japanese and Western standards very mean circumstances. But this is probably too simple. Japanese cotton spinning mills did have all the accoutrements of paternalism. There was the mill dormitory and dining hall, the mill health personnel and dispensary and/or hospital, the mill school with teacher and classrooms, as well as the other side of paternalism, the oftensevere restrictions on what mill workers might do during their nonworking hours. What were the Japanese mill managers trying to accomplish with this panoply of ameliorative institutions? How did these nonpecuniary characteristics of jobs affect labor supply and job choice? In early industrialization, what did Japan's workers value? And how did their tastes vary across different kinds of workers? What were the characteristics of workers attracted by paternalistic institutions?

In what follows, the Japanese cotton spinning mill will be viewed as supplying a bundle of job characteristics relating to wages, pace of work, hazards and health care, and the availability and quality of dormitory life. Workers will be viewed as having preferences with respect to varying

\footnotetext{
${ }^{8}$ Hazama (1964) and Taira (1970) have argued that the commonly understood paternalistic practices of Japanese employers were successful profit-maximizing attempts to curb the extreme instability and unreliability of the early Japanese worker. In Saxonhouse (1976b) the success of these practices is questioned. Much of both Hazama's and Taira's work is based on the experience of the cotton textile industry and, in particular, the experience of the Kanegafuchi Spinning Co. (hereafter Kanebō). From the late 1890s onward Kanebō was the recognized leader in evolving paternalistic practices toward the labor force. Likewise its long-time president Sanji Mutō was the préeminent ideologue for this pattern of employer-employee relations. Examination of the regular-confidential report on the departure of entering monthly cohorts of recruits prepared by Mutō for internal dissemination within Kanebō indicates that even 20 years after Mutō introduced his celebrated changes in Kanebō's Hyōgō mill worker instability had hardly declined and was still extremely high by international standards. Cross-sectionally Kanebō's experience seems no different from other mills in the Japanese cotton spinning industry. Regardless of paternalistic practices or the lack thereof, other mills' turnover experiences hardly differed from that of Kanebō. Moreover, if the pattern of departure which is inferred from the Kanebo data is applied to more general spinning industry recruitment data the mean experience of the industry worker can be accurately tracked right through 1935 . This suggests that the pattern of instability which Fujibayashi (1960) and others have identified for mid-Meiji persisted from the days of Sanji Mutô's managing directorship past the implementation of Japan's Factory Law in 1929 up until the Pacific War.
} 
bundles of job characteristics. Such preferences will be assumed varying with the traits of these workers. Age, experience, education, and other presumptively valuable traits will be viewed as shaping the preferences of workers. ${ }^{9}$ The markets for job characteristics in early industrialization which result from the interaction of firm desires and capabilities with workers' preferences and opportunities have never been studied systematically for any period of any country's economic history. The research reported here for mid-Meiji Japan is intended as a first effort in an important neglected area of inquiry. ${ }^{10}$

\section{THE DATA}

The early development of the Japanese industry presents an unusual opportunity for conducting an investigation into worker preferences and worker quality. In 1897 as discussions in Nōshōmushō (Ministry of Agriculture and Commerce) caused heightened concern among cotton spinning firms that strict factory legislation might be enacted Dai nippon bōseki rengōkai (All Japan Cotton Spinners Association; hereafter, Bōren) established a working group of the representatives of 14 firms, Shokkō jijō chosa i-in (Investigation Committee on Factory Labor), for the purpose of collecting information on the working conditions in the industry. ${ }^{11}$ In an industry whose constituent firms had been reporting to Bōren for more than $\mathbf{8}$ years a remarkably detailed account of their output, input, and costs, it is perhaps not surprising that this committee was exceedingly successful in meeting its charge. ${ }^{12}$ Seventy-one thousand workers in 75 mills were examined. A common unusually quantitatively detailed report in identical format was obtained from each mill: (i) on recruitment practices and payments; (ii) on workers classified by age, work experience, and literacy; (iii) on number and length of rest periods during a working day and on length of shifts and number of days between shift rotation; (iv) on wage payment systems; (v) on expenditure on health care, number of doctors and nurses in attendance, incidence of sickness, injury, and death attributable to particular diseases and other causes; (vi) on prevalence of dormitories and their rules and restrictions, on food costs, and on supervisory and educational personnel costs; and (vii) on the rate of worker absenteeism and on the time pattern of permanent separation from the mill. ${ }^{13}$

${ }^{9}$ Elsewhere in Saxonhouse (1977) it has been established that increasing education and experience were major determinants of productivity change in this industry.

${ }^{10}$ Viewing commodities as bundles of attributes and discussing markets for such commodities in terms of markets for their attributes has been common for some time among economists. See Lancaster (1966), Rosen (1974), and Lucas (1975).

${ }^{11}$ The formation of the committee is discussed in Dai nihon bòseki rengōkai hōkoku (1897).

${ }^{12}$ Some description of the production data reported is given in Saxonhouse (1977).

${ }^{13}$ While the subject being probed is most sensitive the reliability of the data seems 
The summary of this investigation paints an interesting picture of mill life in the late $1890 \mathrm{~s}$. A significant percentage of the total industry labor force was recruited hundreds of miles from where the spinning mills were located. Already in the 1890s, the familiar pattern of Kansai (Ōsaka, Kobe, and Kyōto) mills recruiting girls from Southern Kyūshū and Shikoku, and Kantō (Tōkyō area) mills recruiting girls from northern Honshū had become established. ${ }^{14}$ On recruitment the worker's family received a bonus which on the average was equivalent to approximately 20-days' beginning wages. The typical recruitec was a teen-aged girl. For the spinning mill female labor force as a whole the average age was 19 years, with almost $30 \%$ of the labor force aged 14 years or less.

The young girls who were recruited faced a working day which on the average was almost $12 \mathrm{hr}$ long, with an average of somewhat more than three rest periods interspersed throughout the day. In aggregate these rest periods come to about $1 \mathrm{hr}$ for each shift. Half the mill labor force worked a day shift typically beginning at $6 \mathrm{AM}$, and half worked an evening shift beginning at 6 PM. On the average shifts rotated after an 8-day interval.

A large majority of the female workers did live in company-run dormitories. These dormitories, to some extent, inspired by glowing reports of the early nineteenth-century Lowell, Massachusetts, experience, offered the workers many services and placed many restrictions on the workers' off-the-job activities. ${ }^{15}$ Permission to leave the mill compound was restricted. Mill regulations varied: Some mills allowing 1 or $2 \mathrm{hr}$ outside the mill each day, others allowing none. In practice, these regulations were more of a mill ideal than a practice. Infractions of mill discipline, a less than excellent attendance record, and an otherwise poor work record led to a suspension of the privilege.

Included among the benefits offered workers by mills were subsidized food in company dormitories and health and educational facilities. The implicit food subsidy per month was on average equivalent to a week's wage for an inexperienced female recruit. Also, 63 of the 65 mills reporting on their provision of health care had dispensaries staffed by at least one full-time nurse, while 37 of the mills surveyed offered general educational instruction to its workers.

Having dispensaries in the mills certainly made sense since at one

excellent. For example, the Kanegafuchi Spinning Mill's (hereafter Kanebō) internal documents are virtually identical with what was reported to the Shōkkō jijo chōsa i-in. Some discussion of the Kanebō documents is contained in Saxonhouse (1976b).

${ }^{14}$ After 1924, the exact regional distribution of spinning industry recruits is available in Kōseishō. The distribution in 1924 was quite similar to the regional distribution reported in 1897. And the regional distributions in 1897 and 1924 or as late as 1952 resemble the pattern reported by Nihon bōseki kyokai (the successor association to Bōren).

${ }^{15}$ On the role of foreign models in the development of the spinning industry's dormitory system see Saxonhouse (1974). 
time or another during the course of the year at each mill an average of $75 \%$ of the labor force would become ill. And, while it is difficult to ascertain the quality of health care, the survival rate of mill workers from sickness and accident was excellent. The mills surveyed experienced no more than 4.3 deaths per 1000 workers during 1897 . Given the age distribution of workers in the mills surveyed mill workers experienced a lower mortality rate than the average of the age cohorts from which they were drawn. ${ }^{16}$

Again it is difficult to ascertain the quality of primary education offered. It should be noted that among the 37 mills offering primary education instruction there was on the average but four instructors for each 1000 female workers. Since $30 \%$ of the work force was 14 years of age or under, individual exposure was probably quite limited. This is not surprising. The typically 2 -hr-long classes were scheduled at 7 PM for the day shift and $7 \mathrm{AM}$ for the night shift. The attentiveness of workers coming off the 11-hr working day with only an hour's mealtime in between can only be surmised!

The high worker turnover which was characteristic of the cotton spinning labor force during the entire pre-Pacific War period was certainly indicated in this survey in 1897 . Over $40 \%$ of the newly recruited workers left the mills within the first 6 months of their initial employment. ${ }^{17}$ The average work experience of the spinning industry labor force in 1897 was no more than 1.5 years. Temporary absences from the work place were also high. The rate of absenteeism among dormitory workers during the survey month was $8.3 \% .^{18}$

${ }^{18}$ This result should be qualified. Mortality rate for mill workers has been compared with mortality rates constructed using the Meiji life tables constructed by Morita (1944) and Yasukawa (1971). That the mortality rate in the factories were lower than outside them does not mean that country girls reduced their risk of death by entering mill work. Sickly girls simply did not enter the mills. Workers who became ill might leave the mill, subsequently dying at home from a mill-contracted disease or injury. For a later period reports of this happening are legion. Also note that the mortality rate reported for 1897 is lower than the mortality rates for cotton spinning workers reported in 1907 and 1910. The 1907 rate is 5.4 deaths per 1000 workers; the 1910 rate is 12.6 deaths per 1000 workers. These mortality rates are reported in Noshōmushō (1910) and Ishihara (1913).

${ }^{17}$ This rate of departure is rather lower than what was characteristic of the industry for much of the pre-Pacific War period. This is true at both the individual mill as well as at the aggregate industry level. As footnote 16 indicates the same phenomenon is found in the mortality statistics. See also footnote 5 .

${ }^{18}$ The conditions, good and bad, uncovered by the Bören investigators were soon diffused to Japan's political and economic elites. The celebrated Nōshōmushō report Shokkō jijōo (Condition of Factory Workers) which appeared 5 years later was clearly influenced by Bōren's early work. A large proportion of the materials on textiles in this famous report were directly taken from the 1897 survey. The results of the survey also soon surfaced in Western languages. The very same year Böseki shokkō jijō chōsa gaiyo appeared, La protection ouvrière au Japan drawing very heavily on the Bōren survey was published in 
Internationally speaking, the conditions described in the Bōren report have a patina of familiarity. The dormitories and deportment classes for female workers call to mind Lowell, Massachusetts. The high rates of worker turnover are reminiscent of the Southern Piedmont, and the age of the workers and the accidents described resemble, at least anecdotally, the findings of British parliamentry commissions in the early nineteenth century. What is different in the Japanese case is the auspices and quality of the report on working conditions. The cotton textile industry itself undertook a comprehensive survey. Of all the internationally familiar circumstances in the early history of the Japanese cotton labor force it is only for the Japanese case that such a massive almost universal survey on so many pertinent dimensions was undertaken so early in the industry history. Analysis of this unique body of data should bear not only on the interpretation of the Japanese experience but should more generally inform us of the process of early industrialization.

\section{THE CONCEPTUAL FRAMEWORK FOR THE ANALYSIS OF JOB AND WORKER ATTRIBUTES}

The traditional theoretical treatment of job choice which dates back as far as Adam Smith has stressed wage differentials as compensating for differences in job attributes. Similarly, the historical treatment of job choice in early industrialization has highlighted the importance of working conditions and living environments in addition to wages in the decision to accept and continue factory work. For all the theoretical insight and historical suggestion, there has been virtually no systematic econometric analysis of the market for job characteristics, whether done on contemporary or traditional data. In part the lack of appropriate data has been responsible. In part there has also been the presumption that the forces producing observed wage variation are so varied and so complex as to preclude isolating the impact of individual effect: however, such presumption may fly in the face of a profession with a now long history of performing multiple-regression analysis. It is not clear why price determination in labor markets should be more complex than in any other market where tied sales occur. Indeed, the hedonic reconstruction of demand theory suggests that tied sales and package deals of product characteristics are the rule and not the exception in virtually all market exchange. ${ }^{19}$ With this in mind and given the availability of a rich data set it is appropriate to proceed with this almost unprecedented investigation of workers' preferences with respect to place of employment.

French. The author was the Nōshomushō official Kashiro Saito. The Saito book was later summarized and reviewed in the Economic Journal by Foxwell (1901).

${ }^{19}$ For other applications of the hedonic approach to labor markets see Smith (1976) and Thaler (1974). Both these applications treat only one job characteristic. See also footnote 10. 
The market which is being investigated is hypothesized to consist of firms on the one side that in the context of profit maximization were seeking workers of varying quality and were offering wages and the opportunity to live and work in a mill compound offering many amenities and disamenities. On the other side, workers of varying traits in the course of attempting to maximize utility were seeking high wages and good working conditions and living environments. It is further assumed that firm decisions on the quality mix of workers hired and the mix of amenities and disamenities offered were separable from other firm decisions. Similarly, it is assumed that worker decisions regarding the mix among wages and other amenities were separable from other consumption decisions.

Ignoring random terms the model to be estimated can be written as

$$
\begin{aligned}
W_{i}(Z) & =F^{i}\left(W_{\mathrm{c}}, W_{\mathrm{F}}, Z_{1}, \ldots, Z_{N}, T_{1}, \ldots, T_{\mathrm{K}}\right) \quad i=1, \ldots, N \\
& \equiv \text { demand for job characteristics, } \\
W_{i}(Z) & =G^{i}\left(W_{\mathrm{c}}, Z_{1}, \ldots, Z_{N}, T_{1}, \ldots, T_{K}, M_{1}, \ldots, M_{M}\right) \\
& \equiv \text { supply of job characteristics, }
\end{aligned}
$$

where $W_{i}(Z)$ is the price of the job characteristic $Z_{i} ; W_{\mathrm{c}}$ is money wages available for off-the-job consumption; $W_{\mathrm{I}}$ is money fees available for offthe-job consumption; $T_{j}$ is the $j$ th worker attribute; $M_{k}$ is the $k$ th nonjob firm characteristic. The $W s, Z s$, and $T s$ in the system of demand and supply Eqs. (1) and (2) are assumed to be endogenous. The $M$ s are assumed to be predetermined. Thus, if $M>K+N+1$, the demand equations will be identified.

While data on $Z_{i}, W_{\mathrm{c}}, W_{f}, T_{j}$, and $M$ are potentially available, the absence of explicit markets for individual job characteristics as opposed to jobs or bundles of job characteristics mean that the $W_{i}$ would not normally be available. It has been widely suggested that the $W_{i}$ might be computed from the derivative of the wage explaining regression. Let wages be explained by

$$
\begin{gathered}
W_{\mathrm{c}}=H\left(Z_{1}, \ldots, Z_{N}, T_{1}, \ldots, T_{\mathrm{K}}\right), \\
\text { with }\left(\partial W_{\mathrm{c}}(Z)\right) /\left(\partial Z_{i}\right)=\hat{W}_{i}(Z) .
\end{gathered}
$$

It should be emphasized that estimation of Eq. (3) alone without following through with the estimation of the system of supply and demand equations will not give us the information being sought here. $\hat{W}_{i}(Z)$ may be thought of as a function which traces out the transactions generated by the intersection of buyers of $Z_{i}$ 's compensated demand functions and sellers of $Z_{i}$ 's compensated supply functions. In the markets for job char- 
acteristics being studied here workers clearly differ according to their traits and qualities and firms clearly differ according to their cost conditions if for no other reason than factor prices differed regionally in Japan. Thus, $\hat{W}_{i}(Z)$ is generated by many different demand functions intersecting with many different supply functions. $\hat{W}_{i}(Z)$ will be determined by the distribution of buyers and sellers in the 1897 samples. The slope of $\hat{W}_{i}(Z)$ in $\hat{W}_{i}, Z_{i}$ space is not the slope of a demand curve nor the slope of a supply curve. If we wish to understand the determinants of the transaction prices for each of the job characteristics rather than "simply" the implicit transaction price itself demand and supply functions must be identified and estimated. ${ }^{20}$

\section{THE ESTIMATION OF THE IMPLICIT PRICES OF JOB CHARACTERISTICS}

In the estimation which follows it will be assumed that Eq. (3) is semilogarithmic.

$$
\ln W_{\text {cf }}=\sum a_{i} Z_{i}+\sum b_{j} T_{j}+\sum c_{k} R_{k}+W_{0},
$$

where $W_{\text {cf }} \equiv$ female wage rate; $Z_{1} \equiv$ bonus paid to recruitee; $Z_{2} \equiv$ length of working shift; $Z_{3} \equiv$ length of rest periods during shift; $Z_{4} \equiv$ incidence of sickness and injury at firm; $Z_{5} \equiv$ mortality at firm; $Z_{6} \equiv$ living in dormitory; $Z_{7} \equiv$ if dormitory is occupant, number of free hours per day; $Z_{8} \equiv$ food subsidy for dormitory worker; $Z_{9} \equiv$ company primary and department school instructional personnel per worker; $T_{1} \equiv$ risk of recruit leaving within 6 months; $T_{2} \equiv$ age of worker; $T_{3} \equiv$ relevant experience of worker; $T_{4} \equiv$ rate of absenteeism; $T_{5} \equiv$ literacy of worker; $R_{1} \equiv$ agricultural wage rate in area in which plant is located; $W_{0} \equiv$ constant term. The results of estimating the wage explaining relationship are presented in Table 1. By the standards of semilogarithmic regressions of wage on explanatory variables, the results in Table 1 are most interesting. For a one-tailed test of significance with a .05 critical region, five explanatory variables and the constant term are significant with the expected sign. When the critical region is expanded to $10 \%$ another six explanatory variables become significant.

${ }^{20}$ Even if labor were perfectly mobile $\hat{W}_{i}$ should differ from mill to mill provided the functional form of (3) is nonlinear. This is an issue which may be resolved empirically, but that a nonlinear form for (3) might be hypothesized at all requires some discussion. First, it must be assumed that workers cannot repackage jobs. In the present context this is quite easy to assume. Part-time work was really not feasible at all for mill girls. Also all renumerative work was done within the set mill environment. If mill workers slept in the dormitories and if their access to the world outside was limited they could hardly fail to use company dining halls or company health facilities. Second, it is also assumed that firm technology for designing or producing jobs is not linear. This is a common but, of course, not universally made assumption for production functions. For further discussion of these issues see Rosen (1974) and Lucas (1975). 
TABLE 1

The Estimation of $\ln W=W o+\sum a_{i} Z_{i}+\sum b_{j} T_{j}+\sum c_{k} R_{k}$

\begin{tabular}{|c|c|}
\hline Variable & Coefficient \\
\hline $\begin{array}{l}W o \\
Z_{1} \\
Z_{2} \\
Z_{3} \\
Z_{4} \\
Z_{5} \\
Z_{6} \\
Z_{7} \\
Z_{8} \\
Z_{9} \\
T_{1} \\
T_{2} \\
T_{3} \\
T_{4} \\
T_{5} \\
R_{1}\end{array}$ & $\begin{array}{r}.763 \times 10^{a} \\
-.350 \times 10^{-4} b \\
.362 \times 10^{-1 b} \\
-.438 \times 10^{-1 c} \\
-.289 \times 10^{-2} \\
.259 \times 10^{c} \\
-.190^{c} \\
-.403 \times 10^{-3 b} \\
-.149 \times 10^{-4 c} \\
-.133 \times 10^{2 c} \\
.348 \times 10^{-4} \\
.303 \times 10^{-1 b} \\
.166 \times 10^{-1 b} \\
-.179 \times 10^{-2 c} \\
-.385 \times 10^{-1} \\
.694 \times 10^{-3 a}\end{array}$ \\
\hline
\end{tabular}

${ }^{a}$ Significant at $1 \%$ level.

- Significant at $10 \%$ level.

c Significant at 5\% level.

\section{A. Agricultural Opportunities and Bonii}

In examining each of the explanatory variables seriatum it will first be noticed that, for all the long-distance recruiting, opportunities in the vicinity in which the mill was located have a significant relationship with mill wages. Evaluated at the mean point the elasticity of female mill wages to female agricultural wages is .827 .

The analysis here does not directly tell us the character of the impact of the recruitment bonus on the decision to enter the spinning mill. The sign of the coefficient on $Z_{2}$ does suggest, however, that the recruitment bonus was taken out of future wage payments. A spinning mill recruit receiving the industry-wide average wage and the industry-wide recruitment bonus paid a total of three yen out of future wages for each yen she initially received.

\section{B. Shifts and Rest Periods}

A longer daily shift for a mill force was compensated in higher wages in the same way that longer rest periods during a shift of any given length meant lower wages. That the absolute signs of two coefficients are also statistically insignificant from one another, even if both statistically sig- 
nificantly differ from zero, is reassuring. The size of the coefficient suggests that typically the marginal compensation for additional work by mill hands was less than average compensation. How the derived demand for labor and worker preferences between leisure and work might yield this result is left for future analysis and the statistical identification of the appropriate functions.

\section{Health and Safety}

In assessing health and safety conditions in the mills and their supply and demand, the analysis here is hampered as elsewhere by difficult problems of multicollinearity. The coefficient on sickness and injury is insignificantly different from zero with the wrong sign. On the other hand, the coefficient on mortality is statistically significant from zero with the proper sign. ${ }^{21}$ The magnitude of the coefficient on mortality suggests that the typical female worker receiving the average industry wage would pay somewhat more than $¥ 2$ over her period of employment in order to reduce the risk of mortality by .001 . A thousand workers in the same situation would collectively pay $¥ 2000$ in order to save one life. Given that the annual wages of such workers was $¥ 40-45$, this could be construed as implying that these workers placed a monetary value on life which exceeded the economic potential or human capital embodied in such a life! $!^{22}$

\section{Dormitory Conditions and Free Time}

The remaining job characteristics in the wage explaining regression are all statistically significant from zero. Workers implicitly paid for their dormitory accommodations and food. Firms in 1897 implicitly compensated workers for the restrictions placed on their activities during their leisure. At the same time workers implicitly paid a tuition for the existence and quality of schools within the dormitory compound. While restrictions on leisure demanded compensation, the worker apparently was not indifferent as to what she did while confined within the mill compound.

Inserting sample values for wages and firms with 100 female workers the estimated coefficient on dormitory living implies that an additional worker living in the dormitory would pay an implicit rent equivalent to $8.5 \%$ of actual wages. Such a share for rent in total expenditures

\footnotetext{
${ }^{21}$ The mortality data used in the analysis have been standardized for age. This standardization was accomplished with the Japanese life tables for the 1890s available in Yasukawa and Hirooka (1972).

${ }^{22}$ For other estimates of the value of a human life relying on observed behavior with respect to safety see Smith (1976) and Thaler (1974).
} 
is not out of line with the budget data which are available for almost the same year of the Meiji era (Yokoyama, 1949).

The coefficient on the hours of free time for mill workers living in dormitories while significantly different from zero is exceedingly small. The price of an extra hour of free time outside the mill compound is less than $1 \%$ of a day's wages for most mills. This somewhat surprising result may be rationalized in a number of ways. First, in this one instance the data may be suspect. Sample information on the number of daily hours allowed outside the mill compound was taken by Bōren investigators from firm regulations and not, as in the case of most of the information they collected, from actual firm practice. Alternatively, assuming the data are correct, it does follow that the typical worker already allowed $2 \mathrm{hr}$ did not value additional freedom very highly. That the mill for its part should take this attitude is still something of a puzzle. Elsewhere it has been shown that the runaway rate of mill recruits was so high for so long that mills almost certainly could have cut this rate had they been so inclined (Saxonhouse, 1976b). The mills chose not to do so because they viewed workers' running away from the mill as an acceptable means of separation. Notice in Table 1 even the mills with relatively high rates of retention of newly recruited workers paid such cohorts of recruitees no special premium. The mills were not interested in investing even the small resources necessary to build a work force composed primarily of long-term workers. The low implicit price for lessening mill workers' opportunities to run away is certainly consistent with this view.

The coefficient on food subsidies for workers in the wage explaining regression implies that typical workers implicitly returned approximately $28 \%$ of this subsidy in the form of lower wages. This is yet another puzzling result. If the coefficient estimate is taken seriously, this result is prima facie evidence that arbitrage among job opportunities of varying characteristics was really not possible. It seems most reasonable that at the least there should have been a yen for yen substitution between wages and food subsidies. Or perhaps because the mill was buying in bulk conceivably the worker might have implicitly paid out more than it was costing the firm to provide the subsidized food. Given, however, that packages of job characteristics cannot be untied, the results here are plausible. Given that workers lived in a mill dormitory compound with restricted access to the outside, the firm had to provide dining halls and prepare food for its employees. The inability to cater to individual tastes and to problems inherent in the mass preparation of food may have caused workers to place a low value on what the firm was providing no matter how efficiently the firm might have been performing this function.

It will be noticed that the coefficient on literacy in the wage explaining 
regression is insignificantly different from zero. Notwithstanding that firms did not pay literate workers a premium, workers did implicitly pay firms for the quantity and quality of education offered. For example, if the mills would have doubled the number of instructors or halved the class size, workers would have implicitly paid $5.5 \%$ of the money wages they would otherwise have received in return for this opportunity. Finding evidence for such implicit payments is all the more surprising since, as was pointed out, these classes were attended after the conclusion of a 12-hr day or night shift. ${ }^{23}$

\section{E. Workers' Traits}

While the Japanese cotton spinning mills of 1897 apparently paid no premium to workers for their literacy or for their initial disinclination to run away, the other traits in the wage explaining regression are statistically significant from zero. The coefficient on the rate of absenteeism is, however, sufficiently small that it appears that the typical mill provided little extra compensation for workers with good attendance. This is interesting since already in 1897 quite a few mills were reporting programs of bonii for workers with perfect attendance records. Since there is evidence that such programs did not have a time series impact it should not be too surprising to find that their cross-sectional impact was also quite limited. ${ }^{24}$

If workers did not receive a substantial special premium for good attendance, age and increased experience appear to have brought significant rewards. While multicollinearity hinders any effort at precisely distinguishing the separate impact of increased age from increased experience in this sample, separately they each significantly differ from zero with a $10 \%$ critical region. Taken jointly a small critical region will suffice to reject the null hypothesis. A 20 -year-old with 1.5 years of experience in a firm of some 200 workers might have expected a $5 \%$ increase in wages should she have worked an additional year at her mill. ${ }^{25}$

${ }^{23}$ In this instance as in others more interpretative weight than can be reasonably borne is being placed on significant regression coefficients. The majority of the Japanese mills in 1897 did not provide schools or instructional personnel. The presence or absence of compound schools may well just be a good proxy for overall mill quality.

${ }^{24}$ See footnote 5 .

${ }^{25}$ In Saxonhouse (1976b) using a comprehensive data set from the period 1891-1935 relationships between productivity and experience and wages and experience were found in a general setting to be significant. The coexistence between these relationships and the high turnover and firm disinterest in cutting turnover can be understood if it is recognized that (i) technologically speaking most Japanese mills were almost identical; and (ii) most firms were reluctant to invest in improving the quality of their workers. In this paper it was argued that the improvement in worker skills was worker financed. 


\section{ESTIMATION OF PREFERENCES OF WORKERS WITH VARYING TRAITS}

Having briefly summarized what the estimation of Eq. (3) can tell about the implicit market prices for job characteristics and the institutions of mill paternalism an effort will now be made to look at the determinants of these market prices. Market price is determined by the interaction of supply and demand. It should be the intention here to estimate both these functions. Unfortunately as can be seen from Eqs. (1) and (2), while it is possible to identify the demand for job characteristics using nonjob firm characteristics which do not appear in Eq. (1), there are no variables in (1) available for use as exclusion restrictions in order to identify (2). Worker's traits are assumed to affect both supply and demand functions. Thus, in what follows only demand functions for job characteristics will be estimated.

With only one side of the market firmly identified a full explanation of the determinants of the price of job characteristics cannot be given. Nonetheless, estimation of the demand function alone will still provide an invaluable source of information regarding what workers in the early period of Japan's industrialization valued.

With ten job characteristics and five worker traits, the estimation of a system of demand functions which will serve the purposes of the analysis here is most complex. It is desirable to allow interaction among the demands for job characteristics. At the same time with so many variables, unless considerable structure is imposed on the problem, there is little hope of feasible estimation. Thus, on one hand it will be assumed that workers had transcendental logarithmic preference characteristics, a functional form which offers very rich possibilities for interaction between various job characteristics ${ }^{26}$ and from which a system of demand equations can be derived. On the other hand, it will be assumed that the preference function here is a tree with four branches. ${ }^{27}$ It is hypothesized that the worker, consciously or unconsciously, made decisions on how to allocate her income among four grand categories of off- and on-the-job expenditure.$^{28}$ After the decision to allocate among four grand categories, a decision was made on within-category expenditure. The four categories include the following.

(i) $W \equiv$ Off-the-job consumption: ${ }^{29} \quad W_{\mathrm{c}} \equiv$ off-the-job consumption

${ }^{26}$ A description of transcendental logarithmic utility functions is given in Diewert (1974).

${ }^{27}$ The utility tree approach is described in Strotz $(1957,1959)$.

${ }^{28}$ Income is used here in Becker's sense (1965). In this context Becker defines income as the sum of potential pecuniary and nonpecuniary compensation which might be received by the workers.

${ }^{29}$ These categories are arguably arbitrary, but given the functional form being used here some such choice is necessary. A priori it is clear that it makes no sense to estimate the 
equal to money wages, and $W_{\mathrm{f}} \equiv$ consumption out of bonii paid at time of recruitment. (ii) $Z_{1} \equiv$ Pace of work: $Z_{1 \mathrm{a}} \equiv$ length of rest periods, and $Z_{1 \mathrm{~b}} \equiv$ length of working shift. (iii) $Z_{2}$ Health care: $Z_{2 \mathrm{a}} \equiv$ incidence of sickness and injury, and $Z_{2 \mathrm{~b}} \equiv$ incidence of mortality. (iv) $Z_{3} \equiv$ Availability and quality of dormitory experience: $Z_{3 \mathrm{a}} \equiv$ percentage of workers living in dormitories, $Z_{3 \mathrm{~b}} \equiv$ numbers of hours of time outside mill compound per day, $Z_{3 \mathrm{c}} \equiv$ food subsidy per dormitory worker $\times$ percentage of workers living in dormitories, and $Z_{3 \mathrm{~d}} \equiv$ instructional personnel for company school per worker.

Formally the system being described here can be expressed as follows:

$$
\begin{array}{r}
\ln U=\ln U\left(W_{\mathrm{c}}, W_{\mathrm{f}}, Z_{1 \mathrm{a}}, Z_{1 \mathrm{~b}}, Z_{2 \mathrm{a}}, Z_{2 \mathrm{~b}}, Z_{3 \mathrm{a}}, Z_{3 \mathrm{~b}}, Z_{3 \mathrm{~d}} ; T\right) \\
=\ln U\left[W\left(W_{\mathrm{c}}, W_{\mathrm{f}}\right), Z_{1}\left(Z_{1 \mathrm{a}}, Z_{1 \mathrm{~b}}\right), Z_{2}\left(Z_{2 \mathrm{a}}, Z_{2 \mathrm{~b}}\right),\right. \\
\left.\quad Z_{3}\left(Z_{3 \mathrm{a}}, Z_{3 \mathrm{~b}}, Z_{3 \mathrm{c}}, Z_{3 \mathrm{~d}}\right) ; T\right],
\end{array}
$$

where, as before, $T$ is the traits vector. Assume now that the worker is maximizing her instantaneous utility subject to the constraint that

$$
W-\sum_{i=1}^{3} w_{i} Z_{i}=0
$$

for the grand budget allocation. ${ }^{30}$ The first-order conditions for the maximization of utility can be written

$$
\begin{aligned}
& (\partial \ln U) /(\partial \ln W)=\mu(W / U) \\
& (\partial \ln U) /\left(\partial \ln Z_{i}\right)=\mu\left[\left(W_{i} Z_{i}\right) / U\right] \quad(i=1,2,3),
\end{aligned}
$$

where $\mu$ is the marginal utility of income. From the budget constraint,

$$
\mu / U=\left(\frac{1}{W+\sum_{i=1}^{3} w_{i} Z_{i}}\right)\left(\frac{\partial \ln U}{\partial \ln W}+\sum_{i=1}^{3} \frac{\partial \ln U}{\partial \ln Z_{i}}\right),
$$

so that

$$
(\partial \ln U) /(\partial \ln W)=\left(\frac{W}{W+\sum_{i=1}^{3} w_{i} Z_{i}}\right)\left(\frac{\partial \ln U}{\partial \ln W}+\sum_{i=1}^{3} \frac{\partial \ln U}{\partial \ln Z_{i}}\right) .
$$

The form of the relationship used to approximate the negative logarithm of the utility function is given by

health care branch. In a two-attribute world $Z_{2 \mathrm{a}}$ and $Z_{2 \mathrm{~b}}$ can only be substitutes. This is beyond the realm of plausibility. In any event, since it is not possible to get statistically significant estimates of $W_{z_{2 \mathrm{a}}}$, it will be assumed that $Z\left(Z_{2 \mathrm{a}}, Z_{2 \mathrm{~b}}\right)=Z_{2 \mathrm{~b}}$.

${ }^{30}$ The analytics of utility maximization and the derivation of the system of demand equations will be done for the tree and its four branches. The analytics of within-branch utility maximization, of course, are identical. 


$$
\begin{aligned}
-\ln U & =\alpha_{0}+\alpha_{W} \ln W+\sum_{i=1}^{3} \alpha_{Z i} \ln Z_{i}+\sum_{i=1}^{3} \beta_{W} \beta_{Z i} \ln W \ln Z_{i}, \\
& +\sum_{i=1}^{3} \sum_{j=1}^{3} \beta_{Z_{i} Z_{j}} \ln Z_{i} \ln Z_{i}, \\
& +\sum_{i=1}^{5} \beta_{W T_{i}} \ln W \ln T_{j}+\sum_{i=1}^{3} \sum_{j=1}^{5} \beta_{Z_{i} T_{j}} \ln Z_{i} \ln T_{j} .
\end{aligned}
$$

Using this form with Eq. (8) the following can be obtained

$$
\begin{aligned}
& \alpha_{W}+ \beta_{W Z_{i}} \ln Z_{i}+\sum \beta_{W T_{j}} \ln T_{j} \\
&= \frac{W}{W+\sum W_{i} Z_{i}}\left[\alpha_{W}+\sum \beta_{W Z_{i}}+\sum \beta_{W T_{k}} \ln T_{k}\right. \\
&+\sum\left(\alpha_{Z_{i}}+\beta_{W Z_{i}} \ln W \beta_{Z_{i} Z_{j}} \ln Z_{j}+\sum \beta_{Z_{i} T_{j}} \ln T_{k}\right) \\
& \alpha_{Z_{i}}+\beta_{W Z_{i}} \ln W_{j}+\sum \beta_{Z_{i} Z_{j}} \ln Z_{j}+\sum \beta_{Z_{i} T_{k}} \ln T_{k} \\
&=\frac{W_{i} Z_{i}}{W+\sum W_{j} Z_{j}}\left[\alpha_{W}+\sum \beta_{W Z_{j}} \ln Z_{j}+\sum \beta_{W T_{k}} \ln T_{k}\right] \\
& \quad+\sum\left(\alpha_{Z_{j}}+\beta_{W Z_{j}} \ln W+\sum \beta_{Z_{j} Z_{m}} \ln Z_{j}+\sum \beta_{Z_{m} T_{k}} \ln T_{k}\right) \\
&(i=1,2,3) .
\end{aligned}
$$

Rearranging, one obtains

$$
\begin{aligned}
& \frac{W}{W+\sum W_{i} Z_{i}} \\
& =\frac{\alpha_{W}+\sum \beta_{W Z_{i}} \ln Z_{i}+\sum \beta_{W r_{j}} \ln T_{j}}{\left[\alpha_{W}+\sum \beta_{W Z_{i}} \ln Z_{i}+\sum \beta_{W T_{k}} \ln T_{k}+\sum\left(\alpha_{Z_{i}}+\beta_{W Z_{i}} \ln W\right.\right.} \\
& \left.\left.+\sum \beta_{Z_{i} Z_{j}} \ln Z_{j}+\sum \beta_{Z_{i} T_{k}} \ln T_{k}\right)\right] \\
& W_{i} Z_{i} \\
& \overline{W+\sum W_{i} Z_{i}} \\
& =\frac{\alpha_{Z_{i}}+\beta_{W Z_{i}} \ln W+\sum \beta_{Z_{i} Z_{j}} \ln Z_{j}+\sum \beta_{Z_{i} T_{k}} \ln T_{k}}{\left[\alpha_{W}+\sum \beta_{W Z_{j}} \ln Z_{j}+\sum \beta_{W T_{k}} \ln T_{k}+\sum\left(\alpha_{Z_{j}}+\beta_{W Z_{j}} \ln W\right.\right.} \\
& \left.\left.+\sum \beta_{z_{j} z_{m}} \ln Z_{j}+\sum \beta_{Z_{m} T_{k}} \ln T_{k}\right)\right] \\
& (i=1,2,3) \text {. }
\end{aligned}
$$

The budget-share equations in (11) constitute the first level of the system of demand which will be estimated. Because of the budget constraint, only three of the four equations in (11) are independent. In the empirical work to be reported it is assumed that the budget-share equa- 
tions have additive disturbances with a joint normal distribution. Given the disturbances of any $n-1$ of the budget-share equations, the disturbance of the remaining equation can be determined from the budget constraint. $^{31}$

The estimation of the within-branch share equations will proceed analogously with the first level of estimation. $W\left(W_{\mathrm{c}}, W_{\mathrm{f}}\right), Z_{1}\left(Z_{1 \mathrm{a}}, Z_{1 \mathrm{~b}}\right)$, $Z_{2}\left(Z_{2 \mathrm{a}}, Z_{2 \mathrm{~b}}\right)$, and $Z_{3}\left(Z_{3 \mathrm{a}}, Z_{3 \mathrm{~b}}, Z_{3 \mathrm{c}}, Z_{3 \mathrm{~d}}\right)$ will be separately approximated by a transcendental logarithmic form analogous to (7), and separate blocks of budget-share equations analogous to (11) will be derived.

\section{A. Estimation of Off the Job Consumption Branch ${ }^{32}$}

The results in Table 2 provide the demand part of the system which generates the market data on the relationship between recruitment bonii and wages reviewed earlier. Female workers viewed recruitment bonii and wages as substitutes. A higher recruitment bonus today was a substitute for higher wages throughout the worker's period of employment.

Using the parameters of the demand subsystem a number of elasticities have also been calculated. The "expenditure elasticities" (really "receipt elasticities"') suggest that as workers receive more in wages and recruitment bonii, bonii became relatively less preferred. This is entirely consistent with the expected relation between resources and time preference.

\section{B. Estimation of the Pace of Work Branch}

The results in Table 3 make clear that the maintained hypothesis that mid-Meiji textile workers viewed rest periods during a shift and length of the shift itself as substitutes provides a plausible framework for estimation. Indeed, workers found the length of shift and rest periods during the shift to be very good substitutes. A $1 \%$ increase in the implicit price of either a change in the total length of rest period or a change in the length of a shift led to a better than $2 \%$ increase in implicit expenditure on the other job characteristic. Also, as a female worker had more resources to allocate to the improvement of the quality of her job, the estimated expenditure elasticities taken from the fitted utility function indicate that shortening the working shift was given priority over increased rest periods. This accords well with the historical experience of the cotton spinning companies after 1897 though it would be hard to argue that the

\footnotetext{
${ }^{31}$ The budget-share equations (11) are homogeneous of degree zero in the parameters; hence a normalization of the parameters is required for estimation. The following normalization is adopted: $\sum \alpha=-1$.

${ }^{32}$ To estimate the unknown parameters of the branch budget-share equations and the grand budget-share equations the iterative Zellner $(1962,1963)$ estimation procedure is used. The interactive nonlinear estimation routine used in these procedures employs a combination of Gauss-Newton and the method of steepest ascent.
} 
TABLE 2

Estimation of Off-the-Job Consumption Branch

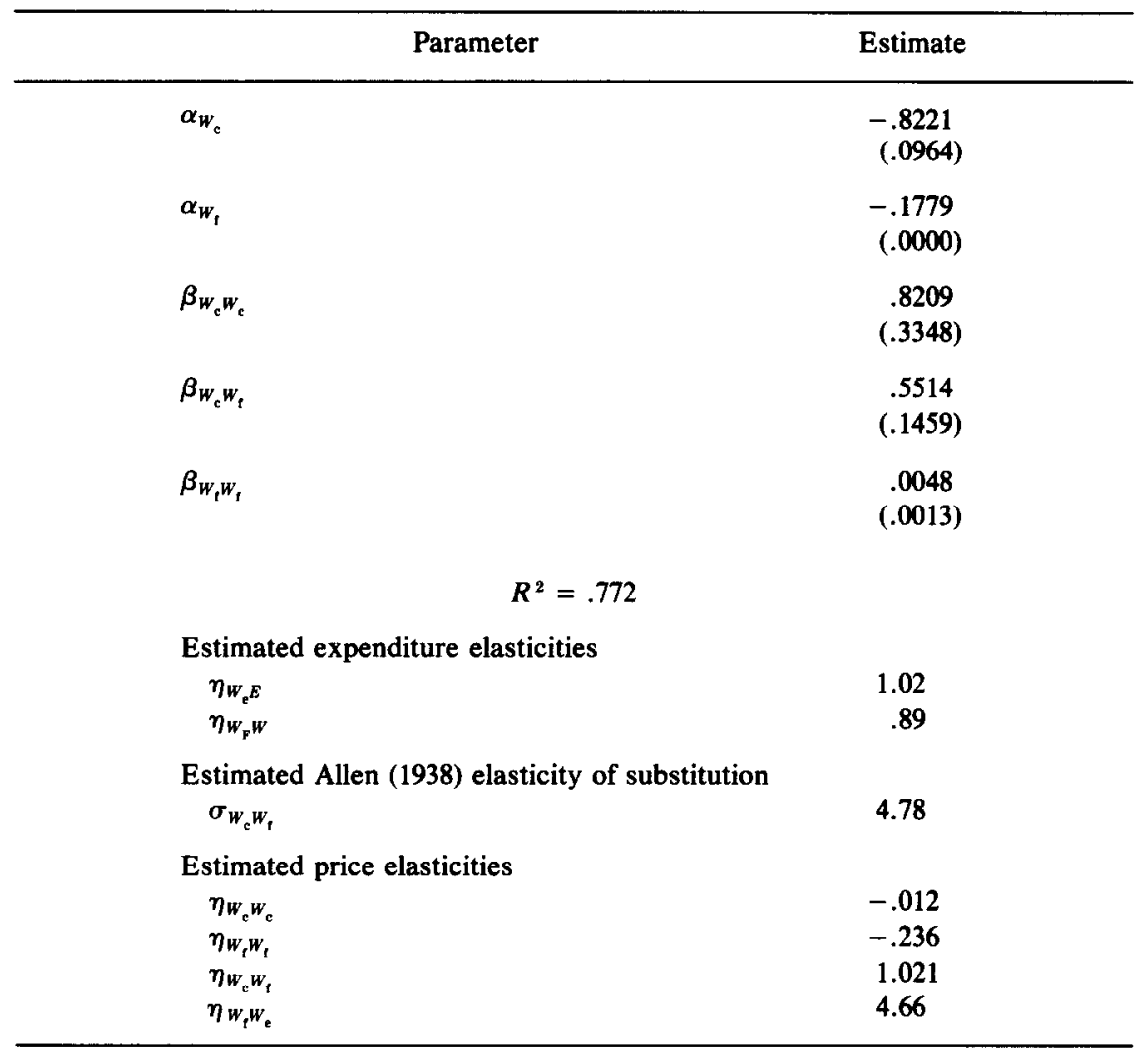

shortening which did occur was largely a result of changing market phenomena. ${ }^{33}$

\section{Availability and Quality of Off-the-Job Mill Compound Experience}

It is instructive to review the estimates for off-the-job but within-themill-compound attributes of jobs presented in Table 4 in light of the earlier discussion of typical implicit prices for these attributes. Despite the low implicit price for free time outside the mill compound, the expenditure elasticity of demand for unchaperoned hours outside the mill is very high. If increasing resources for improving her off-the-job environment became available unsupervised leisure time outside the mill was the preferred attribute. These findings together with the price inelastic demand for free time suggests, even if it does not necessitate, that a bountiful highly

${ }^{33}$ Secularly shifts were reduced from $11 \mathrm{hr}$ of work to $8.5 \mathrm{hr}$ of work in steps under the persistent pressure of the International Labor Organization. 
TABLE 3

Estimation of the Pace of Work Branch

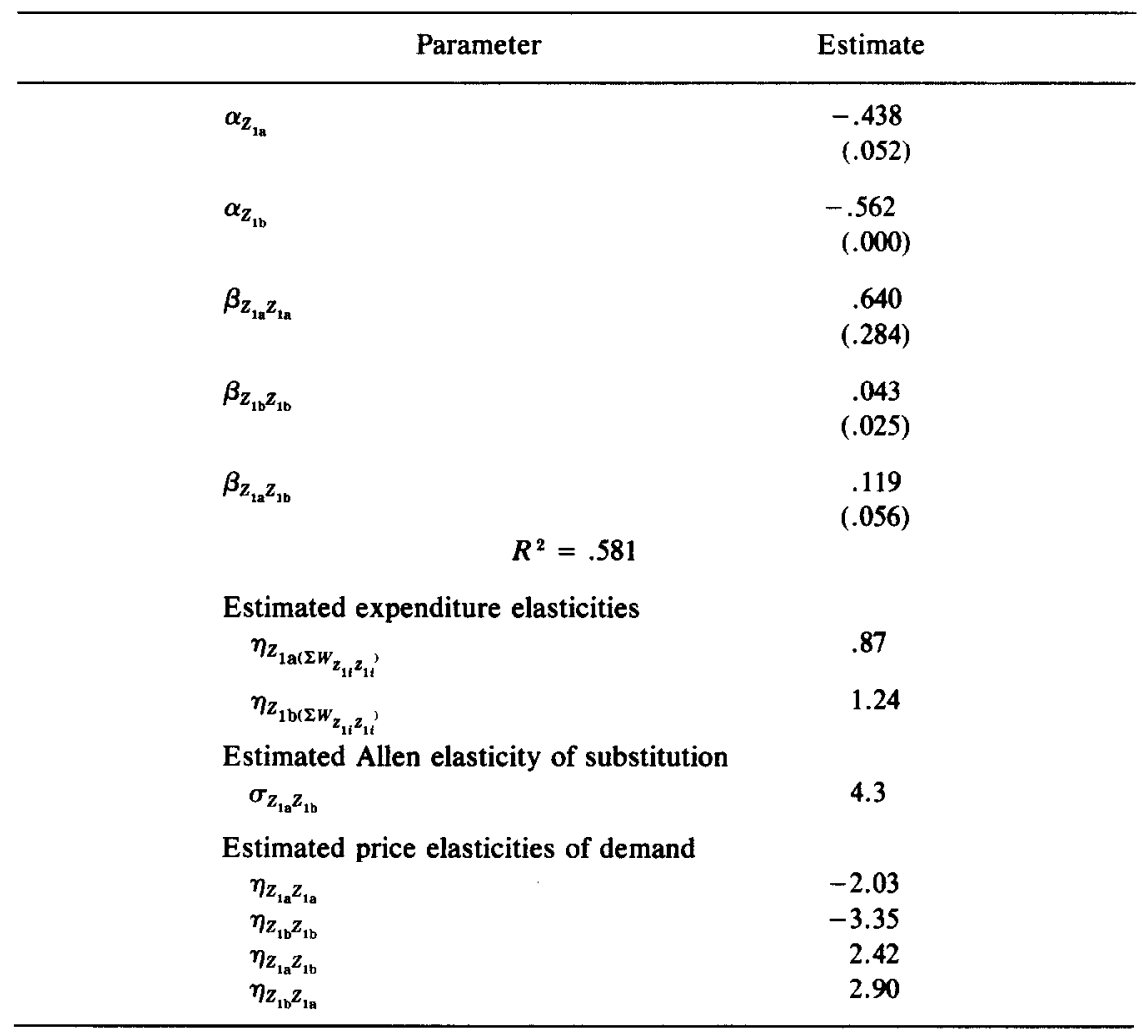

elastic supply of free time from the firm side was responsible for the observed low implicit price of unsupervised time. As noted before, it seems that firms just did not care that much about security. That unsupervised free time and worker education should have relatively high elasticities of expenditure and that shelter and food should have low elasticities of expenditure is entirely consistent in spirit with most demand and budget studies. ${ }^{34}$ Stereotypes of the susceptibility of young Japanese female workers to paternalistic blandishments aside, the same independence which resulted in high runaway rates also resulted in a high preference for free time outside the mill compound over organized "leisure-time" activities provided by management.

${ }^{34}$ Of course, the categories used here are rougher or at least quite different from what is normally found in demand and budget studies. The expenditure elasticity of demand for food subsidies is not the same as expenditure elasticity for food. This does not, however, alter the conclusion drawn. 
TABLE 4

Estimates for Off-the-Job but within-the-Mill-Compound Attributes of Jobs

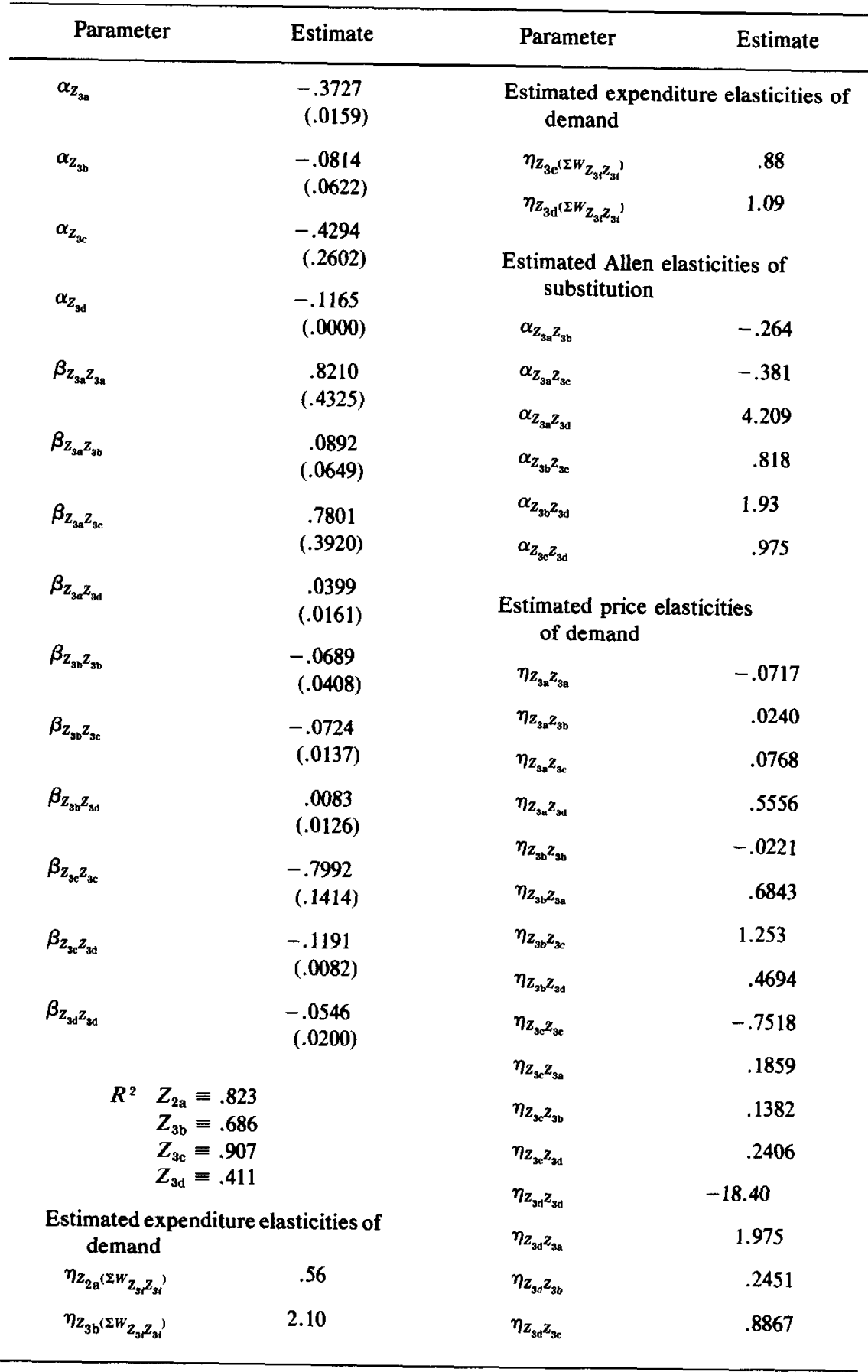


It is also most reasonable that dormitory services should be complementary with free time outside the mill and with food subsidies. A substantial number of female workers bought no dormitory services and hence had little desire to purchase implicitly unsupervised leisure time and diminished, if not negligible, desire to gain company-subsidized food.

While it is difficult to rationalize market prices, explicit, implicit, or otherwise, in the absence of information about the character of supply, the results on worker preferences for education do remain puzzling. $\mathrm{Re}$ call that the implicit price of other available education within the mill was estimated as being very large. Now if the quality of available education is measurable by the teacher-pupil ratio it would seem that the supply of more and better quality primary and department education would be highly price elastic. Given that the expenditure elasticity of demand for education is near unity and that education's own price elasticity of demand is evidently very high it is hard to understand why the implicit price of education was so high for many workers.

\section{THE CHOICE AMONG OFF-THE-JOB GOODS, PACE OF WORK, HEALTH, AND DORMITORY LIFE}

The estimates of each of the branches or demand subsystems allows for the condensing of nine attributes into four: off-the-job goods, pace of work, health, and dormitory life. The estimation of the demand system given in (11) describing the allocation of female worker income on these four attributes conditioned on five workers' traits is given in Table 5.

The expenditure elasticities of demand calculated from the estimated demand system suggest that at very low Beckerian income ${ }^{35}$ workers cared most about wages. As incomes increased higher priority was placed on reducing the risk of mortality, improving on-the-job conditions, and, to a lesser extent, improving dormitory life. Evidence from this cross-section also does well as an indicator of secular trends. Real wages have risen since 1897 and while the prices paid are not known workers have implicitly purchased more safety and improved on-the-job conditions. And while improvement in the quality of dormitory life did occur before the Pacific War the great changes comparable to what happened in safety and shifts were only to come in the late $1950 \mathrm{~s}$.

Too much should not be made of the poor worker's strong preference for money wages. The results in Table 5 on elasticities of substitution and price elasticities of demand are such that even at a low level of Beckerian income workers will be most sensitive to new opportunities to reduce the risk of mortality, slow the pace of work, and improve dormitory life inexpensively.

\footnotetext{
${ }^{35}$ Low Beckerian income is defined in footnote 28.
} 
QUALITY WORKERS AND QUALITY IN JOBS

TABLE 5

Estimation of the Demand System Given in Eq. (11)

\begin{tabular}{|c|c|c|c|c|c|}
\hline Parameter & Estimate & \multicolumn{3}{|c|}{ Parameter } & Estimate \\
\hline$\alpha_{W}$ & $\begin{array}{c}-.7242 \\
(.0510)\end{array}$ & \multicolumn{3}{|c|}{$\beta_{Z_{1} T_{3}}$} & $\begin{array}{c}.0041 \\
(.0158)\end{array}$ \\
\hline$\alpha_{Z_{1}}$ & $\begin{array}{c}-.0921 \\
(.0357)\end{array}$ & \multicolumn{3}{|c|}{$\beta_{Z_{1} T_{4}}$} & $\begin{array}{r}.0114 \\
(.0059)\end{array}$ \\
\hline$\alpha_{z_{2}}$ & $\begin{array}{c}-.0448 \\
(.0109)\end{array}$ & \multicolumn{3}{|c|}{$\beta_{Z_{1} T_{*}}$} & $\begin{array}{c}-.0186 \\
(.0047)\end{array}$ \\
\hline$\alpha_{z_{3}}$ & $\begin{array}{c}-.1389 \\
(.0000)\end{array}$ & \multicolumn{3}{|c|}{$\beta_{Z_{z} z_{2}}$} & $\begin{array}{r}-.0304 \\
(.0121)\end{array}$ \\
\hline$\beta_{W W}$ & $\begin{array}{c}.9007 \\
(.2879)\end{array}$ & \multicolumn{3}{|c|}{$\beta_{Z_{2} Z_{3}}$} & $\begin{array}{c}.0174 \\
(.0063)\end{array}$ \\
\hline$\beta_{W Z_{1}}$ & $\begin{array}{c}.0343 \\
(.0209)\end{array}$ & \multicolumn{3}{|c|}{$\beta_{Z_{2} T_{1}}$} & $\begin{array}{c}.0088 \\
(.0150)\end{array}$ \\
\hline$\beta_{W Z_{2}}$ & $\begin{array}{c}.0108 \\
(.0022)\end{array}$ & \multicolumn{3}{|c|}{$\beta_{Z_{2} T_{2}}$} & $\begin{array}{c}.0694 \\
(.0199)\end{array}$ \\
\hline$\beta_{W z_{3}}$ & $\begin{array}{c}.2343 \\
(.1641)\end{array}$ & \multicolumn{3}{|c|}{$\beta_{Z_{2} T_{3}}$} & $\begin{array}{l}.0332 \\
(.0146)\end{array}$ \\
\hline$\beta_{w T_{t}}$ & $\begin{array}{c}-.2167 \\
(.9834)\end{array}$ & \multicolumn{3}{|c|}{$\beta_{Z_{2} T_{4}}$} & $\begin{array}{c}-.0241 \\
(.0202)\end{array}$ \\
\hline$\beta_{W T_{2}}$ & $\begin{array}{c}.0828 \\
(.0169)\end{array}$ & \multicolumn{3}{|c|}{$\beta_{Z_{2} T_{5}}$} & $\begin{array}{c}.0081 \\
(.0069)\end{array}$ \\
\hline$\beta_{W T_{3}}$ & $\begin{array}{c}.0633 \\
(.0391)\end{array}$ & \multicolumn{3}{|c|}{$\beta_{Z_{3} Z_{3}}$} & $\begin{array}{c}-.0910 \\
(.0229)\end{array}$ \\
\hline$\beta_{W T_{4}}$ & $\begin{array}{c}-.1368 \\
(.0452)\end{array}$ & \multicolumn{3}{|c|}{$\beta_{Z_{3} T_{1}}$} & $\begin{array}{c}.0728 \\
(.0304)\end{array}$ \\
\hline$\beta_{w T_{i}}$ & $\begin{array}{c}.0034 \\
(.0145)\end{array}$ & \multicolumn{3}{|c|}{$\beta_{Z_{3} T_{2}}$} & $\begin{array}{c}-.0380 \\
(1.0492)\end{array}$ \\
\hline $\boldsymbol{\beta}_{\mathbf{Z}_{1} \mathbf{Z}_{1}}$ & $\begin{array}{r}-.0284 \\
(.0001)\end{array}$ & \multicolumn{3}{|c|}{$\beta_{Z_{3} T_{3}}$} & $\begin{array}{r}-.0198 \\
(.0146)\end{array}$ \\
\hline$\beta_{Z_{1} z_{2}}$ & $\begin{array}{c}-.0479 \\
(.0683)\end{array}$ & \multicolumn{3}{|c|}{$\beta_{Z_{3} T_{4}}$} & $\begin{array}{c}.0776 \\
(.0749)\end{array}$ \\
\hline$\beta_{Z_{1} Z_{3}}$ & $\begin{array}{c}.1423 \\
(.1046)\end{array}$ & \multicolumn{3}{|c|}{$\beta_{Z_{3} T_{5}}$} & $\begin{array}{c}-.0093 \\
(.0057)\end{array}$ \\
\hline$\beta_{Z_{1} T_{1}}$ & $\begin{array}{c}+.0527 \\
(.0040)\end{array}$ & \multirow{2}{*}{\multicolumn{2}{|c|}{$\begin{array}{cc}R^{2} & W \\
& Z_{1} \\
& Z_{2} \\
& Z_{3}\end{array}$}} & $\begin{array}{l}.93 \\
.52\end{array}$ & \\
\hline $\boldsymbol{\beta}_{Z_{1} T_{2}}$ & $\begin{array}{c}-.0096 \\
(.0044)\end{array}$ & & & $\begin{array}{l}.59 \\
.69\end{array}$ & \\
\hline
\end{tabular}


TABLE 5 (Continued)

\begin{tabular}{|c|c|c|c|}
\hline Parameter & Estimate & Parameter & Estimate \\
\hline \multicolumn{2}{|c|}{$\begin{array}{l}\text { Estimated expenditure } \\
\text { elasticity of demand }\end{array}$} & \multicolumn{2}{|c|}{$\begin{array}{l}\text { Estimated price elasticity } \\
\text { of demand }\end{array}$} \\
\hline$\eta_{W\left(W+\Sigma W Z_{i}\right)}$ & .84 & $\eta_{Z_{2} w}$ & 3.455 \\
\hline$\eta_{Z_{\jmath}\left(W+\Sigma w_{i} Z_{r}\right)}$ & 1.38 & $\eta_{z_{3} w}$ & 2.875 \\
\hline$\eta_{Z_{2}\left(W+\Sigma W_{i} Z_{i}\right)}$ & 1.47 & $\eta_{W Z_{1}}$ & .2523 \\
\hline$\eta_{Z_{3}\left(W+\Sigma W_{1} Z_{i}\right)}$ & 1.12 & $\eta_{Z_{1} Z_{1}}$ & -1.565 \\
\hline \multicolumn{2}{|c|}{$\begin{array}{l}\text { Estimated Allen elasticities } \\
\text { of substitution }\end{array}$} & $\eta_{Z_{2} Z_{1}}$ & .3121 \\
\hline$\sigma_{W z_{1}}$ & 1.899 & $\eta_{z_{3} Z_{1}}$ & .2569 \\
\hline$\sigma_{W z_{2}}$ & 3.302 & $\eta_{W Z_{z}}$ & .1856 \\
\hline$\sigma_{W Z_{3}}$ & 2.851 & $\eta_{z_{1} z_{z}}$ & .1477 \\
\hline$\sigma_{Z_{1} Z_{2}}$ & 1.919 & $\eta_{Z_{2} Z_{2}}$ & -2.658 \\
\hline$\sigma_{z_{1} z_{3}}$ & 1.670 & $\eta_{Z_{3} Z_{2}}$ & .1012 \\
\hline$\sigma_{\mathbf{Z}_{2} Z_{3}}$ & 1.141 & $\eta_{W Z_{3}}$ & .5129 \\
\hline \multicolumn{2}{|c|}{$\begin{array}{l}\text { Estimated price elasticity } \\
\text { of demand }\end{array}$} & $\eta_{z_{1} z_{3}}$ & .4236 \\
\hline$\eta_{W M}$ & -.1828 & $\eta_{Z_{2} Z_{3}}$ & .3627 \\
\hline$\eta_{Z_{1} W}$ & 2.374 & $\eta_{z_{3} z_{3}}$ & -2.222 \\
\hline
\end{tabular}

\section{TRAITS AND PREFERENCES}

In order to understand how preferences may vary among workers with different traits the sign of the partial derivative of each of the elasticities presented in Table 5 with respect to each of the five worker traits are presented in Table 6.

The impact of traits on preference is understandably most complex. Workers with relatively low Beckerian income and a high propensity to run away exhibit a greater preference for money wages than their more stable counterparts. The same result carries over to workers exhibiting a high rate of absenteeism. The unstable poor worker cared relatively little for the mill environment. In contrast, older, more experienced workers even when poor showed relatively more interest in shortening the workday and improving the dormitory environment. Interesting enough, this concern with the nonwage aspects of the job does not extend to lowering the risk of mortality. Older more experienced workers when poor seemed 
TABLE 6

Signs of the Partial Derivatives of Each of the Elasticities Presented in Table 5 with Respect to Each of the Five Worker Traits

\begin{tabular}{|c|c|c|c|c|c|}
\hline & $T_{1}$ & $T_{2}$ & $T_{3}$ & $T_{4}$ & $T_{\mathrm{s}}$ \\
\hline$\eta_{W\left(w+w_{i} Z_{i}\right)}$ & - & + & + & - & - \\
\hline$\eta_{Z_{1}\left(W+W_{i} Z_{i}\right)}$ & + & - & - & + & - \\
\hline$\eta_{Z_{2}\left(w+w_{1} z_{1}\right)}$ & + & + & + & - & + \\
\hline$\eta_{Z_{3}\left(W+w_{1} Z_{1}\right)}$ & + & - & - & + & + \\
\hline$\sigma_{W Z_{1}}$ & - & + & + & - & - \\
\hline$\sigma_{W Z_{2}}$ & - & + & + & - & + \\
\hline$\sigma_{W Z_{3}}$ & - & + & + & - & - \\
\hline$\sigma_{z_{1} z_{2}}$ & + & + & + & - & - \\
\hline$\sigma_{Z_{1} Z_{3}}$ & + & - & - & + & - \\
\hline$\sigma_{Z_{2} z_{3}}$ & + & + & + & + & + \\
\hline$\eta_{w w}$ & - & + & + & - & - \\
\hline$\eta_{Z_{1} W}$ & - & + & + & - & - \\
\hline$\eta_{Z_{2} W}$ & - & + & + & - & - \\
\hline$\eta_{Z_{3} W}$ & - & + & + & - & + \\
\hline$\eta_{W Z_{1}}$ & - & + & + & - & - \\
\hline$\eta_{Z_{1} z_{1}}$ & + & - & + & + & + \\
\hline$\eta_{Z_{2} Z_{1}}$ & + & + & + & - & - \\
\hline$\eta_{Z_{3} Z_{1}}$ & + & - & - & + & - \\
\hline$\eta_{W Z_{2}}$ & - & + & + & - & + \\
\hline$\eta_{Z_{1} Z_{2}}$ & + & + & + & - & - \\
\hline$\eta_{Z_{2} Z_{2}}$ & + & + & + & - & + \\
\hline$\eta_{Z_{3} Z_{2}}$ & + & + & + & + & + \\
\hline$\eta_{W z_{3}}$ & - & + & + & - & + \\
\hline$\eta_{Z_{1} Z_{3}}$ & + & - & - & + & - \\
\hline$\eta_{z_{2} z_{3}}$ & - & + & + & - & - \\
\hline$\eta_{Z_{3} Z_{3}}$ & + & - & - & + & + \\
\hline
\end{tabular}

less inclined to pay for safety than other workers. Presumably the more experienced workers placed more reliance on themselves and less on the mill environment in the avoidance of risk. Similarly, older workers being closer to retirement or natural death might be viewed as having less to lose in human capital than their younger counterparts.

The findings on the substitution and price elasticities are consistent with the above interpretation of the expenditure elasticities. Workers with high absentee rates and a high propensity to run away found nonpecuniary benefits relatively poorer substitutes for wages than other workers. For such workers the share of wages in the total Beckerian income will be relatively insensitive to changes in implicit prices.

Again for older and more experienced and stable workers the opposite is generally true. For these workers most job characteristics are relatively good substitutes for each other and expenditure shares are relatively sensitive to price changes. 


\section{SUMMARY AND CONCLUSION}

Changes in the quality, morale, and organization of the labor force in Japan's early industrialization in textiles appear to be responsible for the bulk of the improvement during this period in total factor productivity (Saxonhouse 1977). Better education, more experienced labor force, and shorter working hours transformed an industry which could not compete with even Indian yarns in its home market into the major force in world textile markets. Most of these changes in the quality, morale, and organization of the labor force were exogenously determined. The incidence of exposure to government-sponsored primary education changed dramatically during the latter half of the Meiji period. Shifts were lessened in accordance with international pressure, and worker experience increased not because new recruits on the average stayed longer but rather because the industry matured and the one or two workers from each entering cohort who stayed permanently became the large corps of supervisory workers (Saxonhouse, 1976b). That the Japanese textile industry continued for 50 years to have a transient labor force does not mean that the industry's elaborate paternalistic practices were a failure. In all likelihood the industry got the kind of labor force it wanted. Other nations have organized their labor forces differently and have had textile industries using many more men and much more experienced labor. If this is so, what is the meaning of the industry's paternalistic practices? The answer to this question will have two parts. First, what did paternalism mean to labor recruitment, and, second, how did practice of paternalism relate to the choice of technique by the industry. This study begins an attempt to answer the first of these two issues. The attempt is made within the broader setting of trying to understand the overall structure of worker preferences and job choice.

The econometric analysis performed here finds that workers in Japan's early industrialization chose their jobs for both pecuniary and nonpecuniary considerations. In their transactions with their employers, workers exhibited a willingness to pay implicitly for dormitory space they might occupy, for food subsidies, for more time outside the mill compound, and for within-the-mill compound educational opportunities. The workers also exhibited a willingness to pay for on-the-job improvements such as more safety, longer rest periods, and shorter working shifts. Workers were clearly not indifferent to compound and job conditions. This does not mean, however, that a bundle of job characteristics weighted with nonpecuniary benefits was necessarily an efficient means of attracting workers. For example, the econometric analysis presented here suggests workers would have considered themselves better off if resources their employers devoted to food subsidies were given to them directly. Moreover, reactions to job and compound amenities varied from 
worker to worker. The less the Beckerian income the worker received from the mill the stronger the preference for pecuniary benefits. Also, the less a worker's attachment to her job as manifested by high absenteeism and high propensity to run away the stronger her preference for pecuniary benefits. Such workers viewed nonpecuniary amenities as relatively poor substitutes for money. In contrast, older and more experienced workers, seemed to place a relatively higher priority on nonpecuniary benefits and were more sensitive to relative prices in deciding between pecuniary and nonpecuniary benefits.

The association between the traits of stability and positive reaction to the mill and the job environment suggest further manipulation of these variables might have been one way to obtain the more stable work force which was absent from the textile industry in the pre-Pacific War period. Given the package of job characteristics offered during this period, the industry acquired a work force which cared primarily for the wages they were receiving and had little attachment to the job they were performing.

\section{REFERENCES}

Abegglen, J. (1958), The Japanese Factory. Glencoe, Ill.: The Free Press.

Allen, R. G. D. (1938), Mathematical Analysis for Economists. London: Macmillan.

Becker, G. (1965), "A Theory of the Allocation of Time." Economic Journal 75, September. Diewert, W. (1974), "Applications of Duality Theory." In M. Intriligator and D. Kendrick (Eds.), Frontiers of Quantitative Economics. Amsterdam: North-Holland, Vol. 2.

Fei, J., and Ranis, G. (1964), The Development of the Labor Surplus Economy. Homewood, Ill.: Richard D. Irwin.

Foxwell, E. (1901), "The Protection of Workers in Japan." Economic Journal 11, March.

Fujibayashi, K. (1960), "Meiji nijū-nen ni ōkeru waga bōsekigyō rodōsha no ido gensho ni tsuite." In Meiji zenki no rōdō mondai. Tokyo: Ocha no mizu shobu.

Fukuhara, H. (1903), Minami beikoku bōseki jijō. Osaka: Dai nihon bōseki rengōkai.

Gerschenkron, A. (1962), Economic Backwardness in Historical Perspective. Cambridge, Mass.: Belknap Press.

Hazama, H. (1964), Nihon rōmukanrishi kenkyū. Tokyo: Diamond-sha.

Ishihara, O. (1913), Jōkō to kekkaku, Tokyo.

Jorgenson, D. (1961), "The Development of a Dual Economy." Economic Journal 71, June.

Kamisaka, S. (1919), Cotton Mills and Workers in Modern Japan. Osaka: All Japan Spinners Association.

Koseisho, Rōdōsha boshü nenpō, various issues.

Lancaster, K. (1966), "A New Approach to Consumer Theory." Journal of Political Economy 74, 132-156.

Lewis, W. (1954), "Economic Development with Unlimited Supplies of Labor." Manchester School 22, May.

Lucas, R. E. B. (1975), "Hedonic Price Functions." Economic Inquiry 13, 157-179.

Morita, Y. (1944), Jinkō zōka no bunseki. Tokyo: Nihon hyoron sha.

Morris, M. (1960), "The Recruitment of an Industrial Labor Force in India, with British and American Comparisons." Comparative Studies in Society and History 2, April.

Nōshōmushō (1903), shokkō jijō. Tokyo.

Nōshōmushō (1910), Kōjō eisei chōsa shiryō. Tokyo. 
Ohkawa, K. (1955), Nōgyō no keizai bunseki. Tokyo: Taimei-dō.

Ohkawa, K., and Rosovsky, H. (1973), Japanese Economic Growth. Stanford, Calif.: Stanford University Press.

Okochi, K. (1955), Rōdō mondai. Tokyo: Kōbun-dō.

Rosen, S. (1974), "Hedonic Prices and Implicit Product Differentiation in Pure Competition." Journal of Political Economy 82, 34-56.

Rosovsky, H. (1961), Capital Formation in Japan. Glencoe, Ill.: The Free Press.

Report of Select Committee on Factory Children's Labor, London, 1831-1832.

Saxonhouse, G. (1974), "A Tale of Japanese Technological Diffusion in the Meiji Period." Journal of Economic History 34, March.

Saxonhouse, G. (1976a), "Concetti e metodi della scienza economica nelle richerche di storia giapponese." Quaderni storici 31, January-April.

Saxonhouse, G. (1976b), "Country Girls and Communication Among Competitors in the Japanese Cotton Spinning Industry." In H. Patrick (Ed.), Japanese Industrialization and Its Social Consequences. Berkeley, Calif.: University of California Press.

Saxonhouse, G. (1977), "Productivity Change and Labor Absorption in Japanese Cotton Spinning 1891-1935." Quarterly Journal of Economics 91, 195-219.

Smith, R. S. (1976), The Occupational Health and Safety Act. Washington, D.C.: American Enterprise Institute.

Strotz, R. H. (1957), "The Empirical Implications of a Utility Tree." Econometrica 25, April.

Strotz, R. H. (1959), "The Utility Tree-A Correction and Further Appraisal." Econometrica 27, July.

Taira, K. (1970), Economic Development and the Labor Market in Japan. New York Columbia University Press.

Thaler, R. (1974), The Value of Saving a Life: A Market Estimate. Ph.D. Dissertation. Rochester, N.Y.: University of Rochester.

Uno, R. (1913), Shokkō mondai shiryō II. Osaka: Kōgyō kyoiku kai.

Yasuba, Y. (1968), "Keizai-hatten ron ni okeru Meiji kōzō no rirōn to Nihon shihon shugi ronso." Shakai keizai shi gaku 20, January.

Yasuba, Y. (1972-1973), "Modern Economists' Views on the Japanese Economy." Japanese Economic Studies 1, Winter.

Yasukawa, M. (1971), "Nihon no moderu seimeihyo." Mita gakkai zasshi 64, May.

Yasukawa, M., and Hirooka, K. (1972), "Meiji-taisho nenkan no jinkō suikei to jinko dōtai." Mita gakkai zasshi 65, February/March.

Yokoyama, G. (1949), Nihon no kaso shakai. Tokyo: Ogura shobo.

Zellner, A. (1962), "An Efficient Method of Estimating Seemingly Unrelated Regressions and Tests for Aggregation Bias." Journal of the American Statistical Association 57, June.

Zellner, A. (1963), "Estimators for Seemingly Unrelated Regressions Equations: Some Exact Finite Sample Results." Journal of the American Statistical Association 58, December. 